\begin{tabular}{|c|c|}
\hline \multirow{3}{*}{ 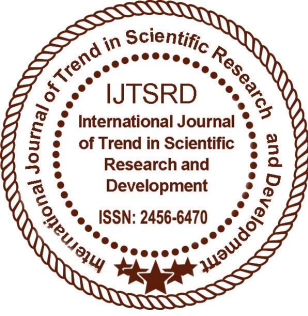 } & $\begin{array}{l}\text { International Journal of Trend in Scientific } \\
\text { Research and Development (IJTSRD) }\end{array}$ \\
\hline & International Open Access Journal \\
\hline & ISSN No: 2456 - 6470 | www.ijtsrd.com | Volume - 2 | Issue - 4 \\
\hline
\end{tabular}

\title{
Service Quality and Patient Satisfaction in Public Hospitals (A Study of District Pulwama and Shopian in J\&K)
}

\author{
Suheel Azad ${ }^{1,}$ Mohd. Ashraf Mir ${ }^{2}$, Dr. R. C. Gupta ${ }^{3,}$ Dr.Vibha Doorwar ${ }^{4,}$ Dr. Damsaz Indrabi \\ ${ }^{1}$ Research Scholar, Jiwaji University, Gwalior, M.P., India \\ ${ }^{2}$ Research Scholar, Jiwaji University, Gwalior, M.P., India \\ ${ }^{3}$ Professor, Department of Commerce, MLB Govt. College of Excellence, Gwalior, M.P., India \\ ${ }^{4}$ Associate Professor, Department of Political Science MLB Govt. College of Excellence, Gwalior \\ ${ }^{5}$ Social Scientists Govt. Degree College Pulwama Department of History, Gwalior, M.P., India
}

\section{ABSTRACT}

Quality is one of the key parameter in order to measure the performance of a product or service and ultimately it referred to organizational performance. Customers are the key player, who played - a significant role to measure the quality of the product or services. However, to measure the quality of services is quite difficult as compare to the product quality due to its intangible nature. This study is intended to investigate the level of quality of healthcare services delivered to patients by the public hospitals in two districts of Jammu and Kashmir namely Shopian and Pulwama. Currently, healthcare system in Jammu and Kashmir is comprised of public hospitals, healthcare units and dispensaries, which are not sufficient to meet the healthcare requirements of people. This study aims to investigate, quality of services delivered to patients by public hospitals in two districts of Jammu and Kashmir.

Keywords: Service Quality, Patient Satisfaction, Public Hospital

\section{INTRODUCTION}

"HEALTH IS STATE OF COMPLETE PHYSICAL, MENTAL AND SOCIAL WELL BEING AND NOT MERELY AN ABSENCE OF DISEASE OR DEFORMITY"

The above definition is what is stated in the Constitution of World Health Organization. Framing
Policies and Programs in every sphere of life is a routine and continuous affair so is in the Health sector. 'Health is Wealth' and Good health of population is the 'Wealth of Nation'. In healthcare organizations, service quality and patients satisfaction is getting considerable attentions and this issue is considered in their strategic planning process. Patients perceptions about the services provided by particular health care organizations also effect the image and profitability of the hospital. Increased patient expectations about the service quality had realized the healthcare service providers, to identify the key determinants that are necessary to improve healthcare services that cause patients satisfaction. The personnel, front line employees and the support staff are most important in providing better facilities thereby enhancing customer satisfaction. Effective customer service comes from satisfied employees. A comparative analysis of the government expenditure on Defense, Education and Health in developed and developing countries reveal that the investment on health sector in India is lowest in the world. The figures reveals that the percentage of total expenditure on Health sector is India is only 4.2 percent as per the World Development Report 2009. A comparative analysis of health investment reveals that the performance of Sri Lanka, Bangladesh in the health sector is more satisfactory compared to India. The health investment in Bangladesh is about 5.3\%, Sri Lanka 6.2\%, Pakistan 2.05\%, UK 15.7\%, and USA 
$18.6 \%$ while in Germany it is $20 \%$. The figures show that there is certainly a downward trend in health investment in India (Dwarakanath et al. 2015) ${ }^{1}$. Health care of a country needs special attentions from the government as quality of healthcare provides hope and relief to the patients and their dependents. It also helps to maintain a healthy human capital that contributes in the development of the country. Health care of a country needs special attentions from the government as quality of healthcare provides hope and relief to the patients and their dependents. It also helps to maintain a healthy human capital that contributes in the development of the country.

\section{OBJECTIVES OF STUDY:}

1. To examine how far people are satisfied with the quality services being provided in Government health care institutions?

2. To identify the challenges and suggest measures to deal with efficiently.

\section{REVIEW OF LITERATURE:}

Freidson (1984) $)^{2}$ also felt that to improve and maintain service delivery in Hospitals it is extremely important to have an efficient Human Resource department. In many cases, these changes can be best conceptualized as a movement away from the domination of healthcare organizations by professionals and professional knowledge, through a simultaneous increase in 'customer' orientation.

Schneider et al. (1996) ${ }^{3}$ regarding quality of medical care although patients are the obvious source of information, previous evidence has shown that employee surveys are also valid when trying to predict customer perceptions of satisfaction and service quality, as employee and customer perceptions of service quality are positively related.

Saha et al. (1998) ${ }^{4}$ found that public provision for health care services at no charge or nominal cost is common in low-income countries. Government, providers and clients at times also agree that the quality of these highly subsidized services is inadequate and because free services, medicines and medical equipment are often under-funded or insufficient to meet demand, they are vulnerable to agents who collect unofficial charges.

Braunsberger et al. (2002) ${ }^{5}$ showed that the patients with low level of education perceived the performance to be higher than the patients with higher level of education. More educated patients tend to be less satisfied because they have higher expectations or they apply stringent standards while evaluating the care provided.

International Finance Corporation (2007) ${ }^{6}$ several private primary care providers reported difficulties referring their patients to public sector secondary care facilities, as public facilities did not accept the diagnoses made by the private providers and often required the patient to restart the consultation process.

Weinger et al. (2007) ${ }^{7}$ showed that overarching poverty is regarded as the primary threat to women's health in Africa, as lack of money is stated as the primary obstacle barring women from maintaining good health. The women in this study blamed living in poverty for their inability to buy drugs and afford medical care.

\section{METHODOLOGY:}

The data has been collected from primary sources by introduction of questionnaire.

\section{UNIVERSE STUDY:}

The study has been conducted in 2 district hospitals and 6 Sub-district hospitals of district Pulwama and Shopian in Jammu and Kashmir during January 2018.

\section{ANALYSIS AND INTERPRETATION OF DATA:}

Following are the satisfaction level of service quality of patients towards public hospitals in two district hospitals (Shopian and Pulwama) and six sub-district hospitals (Pampore, Tral, Rajpora, Zanipora, Keller and Vehil) in a state of Jammu and Kashmir 
Table 1 Level of satisfaction with respect to registration:

\begin{tabular}{|c|c|c|c|c|c|c|c|c|c|c|c|c|c|}
\hline \multirow[t]{4}{*}{$\begin{array}{l}\text { Name of } \\
\text { Hospitals }\end{array}$} & \multirow{4}{*}{$\begin{array}{l}\text { No. } \\
\text { of } \\
\text { Resp- } \\
\text { ond- } \\
\text { ents }\end{array}$} & \multicolumn{2}{|c|}{ Gender } & \multirow{4}{*}{$\begin{array}{l}\text { Aver- } \\
\text { age } \\
\text { Age }\end{array}$} & \multicolumn{4}{|c|}{$\begin{array}{l}\text { Educational } \\
\text { qualifications }\end{array}$} & \multicolumn{5}{|c|}{$\begin{array}{l}\text { Level of satisfication/ } \\
\text { Dissatisfication }\end{array}$} \\
\hline & & \multirow{3}{*}{$\mathrm{M}$} & \multirow{3}{*}{$F$} & & \multirow{3}{*}{$\begin{array}{l}\text { Sec- } \\
\text { onda- } \\
\text { ry }\end{array}$} & \multirow{3}{*}{$\begin{array}{l}\text { Hig- } \\
\text { her } \\
\text { sec. }\end{array}$} & \multirow{3}{*}{$\begin{array}{l}\text { Abo- } \\
\text { ve }\end{array}$} & \multirow{3}{*}{$\begin{array}{l}\text { Illi- } \\
\text { ter- } \\
\text { ate }\end{array}$} & & & & & \\
\hline & & & & & & & & & $\begin{array}{l}\text { Highly } \\
\text { Satis- } \\
\text { ficati- } \\
\text { on }\end{array}$ & $\begin{array}{l}\text { Some } \\
\text { What } \\
\text { Sat. }\end{array}$ & Average & $\begin{array}{l}\text { some } \\
\text { what } \\
\text { dis. } \\
\text { sat. }\end{array}$ & $\begin{array}{l}\text { Highly } \\
\text { Dis- } \\
\text { satisfic- } \\
\text { ation }\end{array}$ \\
\hline & & & & & & & & & 5 & 4 & 3 & 2 & 1 \\
\hline $\begin{array}{l}\text { Pulwama } \\
\text { District } \\
\text { Hospital }\end{array}$ & 25 & 10 & 15 & 39 & 9 & 6 & 3 & 7 & 5 & 4 & 9 & 4 & 3 \\
\hline $\begin{array}{l}\text { Shopian } \\
\text { District } \\
\text { Hospital }\end{array}$ & 25 & 15 & 10 & 3 & 10 & & & $5 / 7$ & 4 & 5 & 8 & 5 & 3 \\
\hline $\begin{array}{l}\text { Pam;pore } \\
\text { Sub-dist. } \\
\text { Hospital }\end{array}$ & 25 & 14 & 11 & & 5 & 9 & & 10 & & 3 & 7 & 4 & 4 \\
\hline $\begin{array}{l}\text { Tral } \\
\text { Sub-dist. } \\
\text { Hospital }\end{array}$ & 25 & 16 & 9 & & 6 า1 & 8 at: & 2 na & 90 & & & 4 & 5 & 5 \\
\hline $\begin{array}{l}\text { Rajpora } \\
\text { Sub-dist. } \\
\text { Hospital }\end{array}$ & 25 & 12 & 13 & 39 & 7 & 6 & 2 & 10 & 7 & 6 & 5 & 5 & 2 \\
\hline $\begin{array}{l}\text { Vehil } \\
\text { Sub-dist. } \\
\text { Hospital }\end{array}$ & 25 & 9 & 16 & & 4 & 8 & 1 & 12 & 4 & & 7 & 5 & 4 \\
\hline $\begin{array}{l}\text { Zanipora } \\
\text { Sub-dist. } \\
\text { Hospital } \\
\end{array}$ & 25 & 17 & 8 & 39 & & 5 & 2 & 11 & 4 & 6 & 5 & 4 & 6 \\
\hline \multirow[t]{2}{*}{$\begin{array}{l}\text { Keller } \\
\text { Sub-dist. } \\
\text { Hospital } \\
\end{array}$} & 25 & 11 & 14 & 39 & 6 & 6 & 3 & 10 & 3 & 5 & 7 & 5 & 5 \\
\hline & 200 & 104 & 96 & 39 & 54 & 54 & 18 & 74 & 40 & 39 & 52 & 37 & 32 \\
\hline
\end{tabular}




\section{Level of satisfaction with respect to approach of doctors and paramedical staff with patients}

Table 2

\begin{tabular}{|c|c|c|c|c|c|c|c|c|c|c|c|c|c|}
\hline \multirow[t]{5}{*}{$\begin{array}{l}\text { Name of } \\
\text { Hospitals }\end{array}$} & \multirow{5}{*}{$\begin{array}{l}\text { No. } \\
\text { of } \\
\text { Resp- } \\
\text { ond- } \\
\text { ents }\end{array}$} & \multicolumn{2}{|c|}{ Gender } & \multirow{5}{*}{$\begin{array}{l}\text { Aver- } \\
\text { age } \\
\text { Age }\end{array}$} & \multirow{2}{*}{\multicolumn{4}{|c|}{$\begin{array}{l}\text { Educational } \\
\text { qualifications }\end{array}$}} & \multirow{2}{*}{\multicolumn{5}{|c|}{$\begin{array}{l}\text { Level of satisfication/ } \\
\text { Dissatisfication }\end{array}$}} \\
\hline & & \multirow{4}{*}{$\mathrm{M}$} & \multirow{4}{*}{$\mathrm{F}$} & & & & & & & & & & \\
\hline & & & & & \multirow{3}{*}{$\begin{array}{l}\text { Sec- } \\
\text { onda- } \\
\text { ry }\end{array}$} & \multirow{3}{*}{$\begin{array}{l}\text { Hig- } \\
\text { her } \\
\text { sec. }\end{array}$} & \multirow{3}{*}{$\begin{array}{l}\text { Abo- } \\
\text { ve }\end{array}$} & \multirow{3}{*}{$\begin{array}{l}\text { Illi- } \\
\text { ter- } \\
\text { ate }\end{array}$} & & & & & \\
\hline & & & & & & & & & $\begin{array}{l}\text { Highly } \\
\text { Satis- } \\
\text { ficati- } \\
\text { on }\end{array}$ & $\begin{array}{l}\text { Some } \\
\text { What } \\
\text { Sat. }\end{array}$ & Average & $\begin{array}{l}\text { some } \\
\text { what } \\
\text { dis. } \\
\text { sat. }\end{array}$ & $\begin{array}{l}\text { Highly } \\
\text { Dis- } \\
\text { satisfic- } \\
\text { ation }\end{array}$ \\
\hline & & & & & & & & & 5 & 4 & 3 & 2 & 1 \\
\hline $\begin{array}{l}\text { Pulwama } \\
\text { District } \\
\text { Hospital }\end{array}$ & 25 & 10 & 15 & 39 & 9 & & 3 & 7 & 6 & 4 & 7 & 4 & 4 \\
\hline $\begin{array}{l}\text { Shopian } \\
\text { District } \\
\text { Hospital }\end{array}$ & 25 & 15 & 10 & 39 & & 6 & 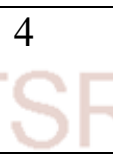 & 5 & & 4 & 9 & 4 & 3 \\
\hline $\begin{array}{l}\text { Pam;pore } \\
\text { Sub-dist. } \\
\text { Hospital }\end{array}$ & 25 & 14 & 11 & 39 & 5 & 9 & Ona & 10 & 4 & 6 & 7 & 3 & 5 \\
\hline $\begin{array}{l}\text { Tral } \\
\text { Sub-dist. } \\
\text { Hospital }\end{array}$ & 25 & 16 & 9 & 39 & 6 & 8 & 2 & 9 & $\begin{array}{l}5 \\
d\end{array}$ & 3 & 8 & 5 & 4 \\
\hline $\begin{array}{l}\text { Rajpora } \\
\text { Sub-dist. } \\
\text { Hospital }\end{array}$ & 25 & 12 & 13 & & 7 & $6=V$ & $20 \%$ & 10 & 3 & 4 & 4 & 8 & 6 \\
\hline $\begin{array}{l}\text { Vehil } \\
\text { Sub-dist. } \\
\text { Hospital }\end{array}$ & 25 & 9 & 16 & 39 & 4 & & 1 & 12 & 2 & 6 & 9 & 4 & 4 \\
\hline $\begin{array}{l}\text { Zanipora } \\
\text { Sub-dist. } \\
\text { Hospital }\end{array}$ & 25 & 17 & 8 & 39 & & 5 & 2 & 11 & 6 & & 7 & 4 & 3 \\
\hline $\begin{array}{l}\text { Keller } \\
\text { Sub-dist. } \\
\text { Hospital }\end{array}$ & 25 & 11 & 14 & 39 & 6 & 6 & 3 & 10 & 1 & 5 & 6 & 4 & 9 \\
\hline & 200 & 104 & 96 & 39 & 54 & 54 & 18 & 74 & 32 & 37 & 57 & 36 & 38 \\
\hline
\end{tabular}




\section{Level of satisfaction with respect of providing free medicines to patients}

Table 3

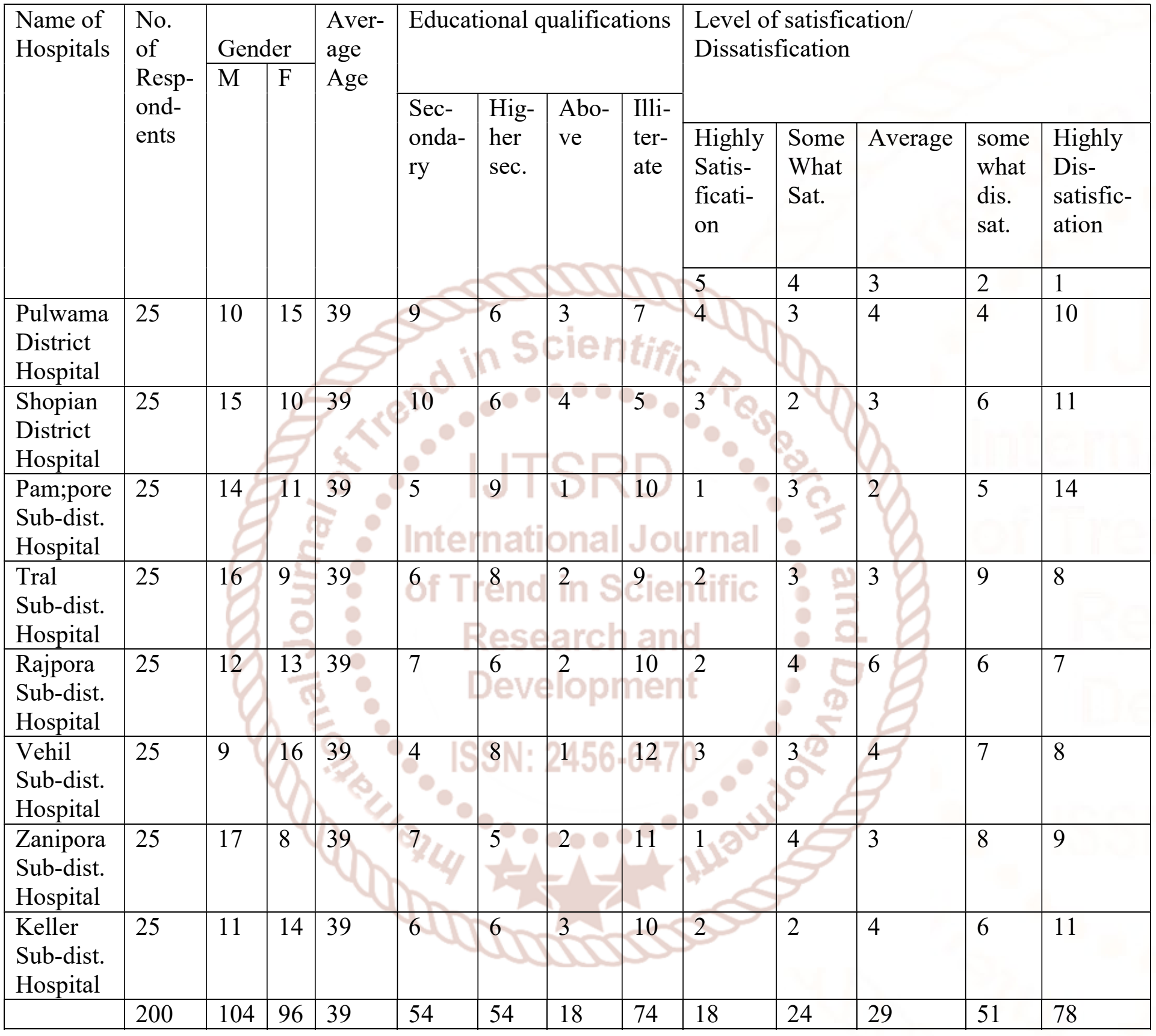




\section{Level of satisfaction with respect to operation procedures}

Table 4

\begin{tabular}{|c|c|c|c|c|c|c|c|c|c|c|c|c|c|}
\hline \multirow[t]{5}{*}{$\begin{array}{l}\text { Name of } \\
\text { Hospitals }\end{array}$} & \multirow{5}{*}{$\begin{array}{l}\text { No. } \\
\text { of } \\
\text { Resp- } \\
\text { ond- } \\
\text { ents }\end{array}$} & \multicolumn{2}{|c|}{ Gender } & \multirow{5}{*}{$\begin{array}{l}\text { Aver- } \\
\text { age } \\
\text { Age }\end{array}$} & \multirow{2}{*}{\multicolumn{4}{|c|}{$\begin{array}{l}\text { Educational } \\
\text { qualifications }\end{array}$}} & \multirow{2}{*}{\multicolumn{5}{|c|}{$\begin{array}{l}\text { Level of satisfication/ } \\
\text { Dissatisfication }\end{array}$}} \\
\hline & & \multirow{4}{*}{$\mathrm{M}$} & \multirow{4}{*}{$\mathrm{F}$} & & & & & & & & & & \\
\hline & & & & & \multirow{3}{*}{$\begin{array}{l}\text { Sec- } \\
\text { onda- } \\
\text { ry }\end{array}$} & \multirow{3}{*}{$\begin{array}{l}\text { Hig- } \\
\text { her } \\
\text { sec. }\end{array}$} & \multirow{3}{*}{$\begin{array}{l}\text { Abo- } \\
\text { ve }\end{array}$} & \multirow{3}{*}{$\begin{array}{l}\text { Illi- } \\
\text { ter- } \\
\text { ate }\end{array}$} & & & & & \\
\hline & & & & & & & & & $\begin{array}{l}\text { Highly } \\
\text { Satis- } \\
\text { ficati- } \\
\text { on }\end{array}$ & $\begin{array}{l}\text { Some } \\
\text { What } \\
\text { Sat. }\end{array}$ & Average & $\begin{array}{l}\text { some } \\
\text { what } \\
\text { dis. } \\
\text { sat. }\end{array}$ & $\begin{array}{l}\text { Highly } \\
\text { Dis- } \\
\text { satisfic- } \\
\text { ation }\end{array}$ \\
\hline & & & & & & & & & & 4 & 3 & 2 & 1 \\
\hline $\begin{array}{l}\text { Pulwama } \\
\text { District } \\
\text { Hospital }\end{array}$ & 25 & 10 & 15 & 39 & 9 & & & 7 & 4 & 3 & 5 & 4 & 9 \\
\hline $\begin{array}{l}\text { Shopian } \\
\text { District } \\
\text { Hospital }\end{array}$ & 25 & 15 & 10 & & 10 & 6 & 4 & 5 & & 2 & 3 & 6 & 10 \\
\hline $\begin{array}{l}\text { Pam;pore } \\
\text { Sub-dist. } \\
\text { Hospital }\end{array}$ & 25 & 14 & 11 & 39 & & rend & 1na & 100 & 1 rnal & 3 & 4 & 5 & 12 \\
\hline $\begin{array}{l}\text { Tral } \\
\text { Sub-dist. } \\
\text { Hospital }\end{array}$ & 25 & 16 & 90 & $\begin{array}{r}39 \\
0 \\
\end{array}$ & 6 & 8 & 2 & 9 & 2 & 3 & 3 & 4 & 13 \\
\hline $\begin{array}{l}\text { Rajpora } \\
\text { Sub-dist. } \\
\text { Hospital }\end{array}$ & 25 & 12 & 13 & $\begin{array}{l}39 \\
0\end{array}$ & 7 & 6 & 2 & 10 & 2 & & 4 & 6 & 9 \\
\hline $\begin{array}{l}\text { Vehil } \\
\text { Sub-dist. } \\
\text { Hospital }\end{array}$ & 25 & 9 & 16 & & & 8 & 1 & 12 & 3 & 3 & 4 & 7 & 8 \\
\hline $\begin{array}{l}\text { Zanipora } \\
\text { Sub-dist. } \\
\text { Hospital }\end{array}$ & 25 & 17 & 8 & 39 & 7 & 5 & 2 & 11 & 1 & 4 & 3 & 6 & 11 \\
\hline \multirow{2}{*}{$\begin{array}{l}\text { Keller } \\
\text { Sub-dist. } \\
\text { Hospital }\end{array}$} & 25 & 11 & 14 & 39 & 6 & 6 & 3 & 10 & 2 & 2 & 4 & 8 & 9 \\
\hline & 200 & 104 & 96 & 39 & 54 & 54 & 18 & 74 & 19 & 24 & 30 & 46 & 81 \\
\hline
\end{tabular}




\section{Level of satisfaction with respect to post operation part}

Table 5

\begin{tabular}{|c|c|c|c|c|c|c|c|c|c|c|c|c|c|}
\hline \multirow[t]{5}{*}{$\begin{array}{l}\text { Name of } \\
\text { Hospitals }\end{array}$} & \multirow{5}{*}{$\begin{array}{l}\text { No } \\
\text {. of } \\
\text { Re } \\
\text { sp- } \\
\text { on } \\
\text { d- } \\
\text { ent } \\
\text { s }\end{array}$} & \multirow{2}{*}{\multicolumn{2}{|c|}{ Gender }} & \multirow{5}{*}{$\begin{array}{l}\text { Aver- } \\
\text { age } \\
\text { Age }\end{array}$} & \multirow{2}{*}{\multicolumn{4}{|c|}{$\begin{array}{l}\text { Educational } \\
\text { qualifications }\end{array}$}} & \multirow{2}{*}{\multicolumn{5}{|c|}{$\begin{array}{l}\text { Level of satisfication/ } \\
\text { Dissatisfication }\end{array}$}} \\
\hline & & & & & & & & & & & & & \\
\hline & & \multirow{3}{*}{$\mathrm{M}$} & \multirow{3}{*}{$\mathrm{F}$} & & \multirow{3}{*}{$\begin{array}{l}\text { Sec- } \\
\text { onda- } \\
\text { ry }\end{array}$} & \multirow{3}{*}{$\begin{array}{l}\text { Hig- } \\
\text { her } \\
\text { sec. }\end{array}$} & \multirow{3}{*}{$\begin{array}{l}\text { Abo- } \\
\text { ve }\end{array}$} & \multirow{3}{*}{$\begin{array}{l}\text { Illi- } \\
\text { ter- } \\
\text { ate }\end{array}$} & & & & & \\
\hline & & & & & & & & & $\begin{array}{l}\text { Highly } \\
\text { Satis- } \\
\text { ficati- } \\
\text { on }\end{array}$ & $\begin{array}{l}\text { Some } \\
\text { What } \\
\text { Sat. }\end{array}$ & Average & $\begin{array}{l}\text { some } \\
\text { what } \\
\text { dis. } \\
\text { sat. }\end{array}$ & $\begin{array}{l}\text { Highl } \\
\text { y } \\
\text { Dis- } \\
\text { satisfi } \\
\text { c- } \\
\text { ation }\end{array}$ \\
\hline & & & & & & & & & 5 & 4 & 3 & 2 & 1 \\
\hline $\begin{array}{l}\text { Pulwama } \\
\text { District } \\
\text { Hospital }\end{array}$ & 25 & 10 & 15 & 39 & 9 & 6 & 3 & & 4 & 4 & 5 & 5 & 7 \\
\hline $\begin{array}{l}\text { Shopian } \\
\text { District } \\
\text { Hospital }\end{array}$ & 25 & 15 & 10 & 39 & 10 & 6 & 4 & 5 & & & 3 & 7 & 8 \\
\hline $\begin{array}{l}\text { Pam;por } \\
\text { e } \\
\text { Sub-dist. } \\
\text { Hospital }\end{array}$ & 25 & 14 & 11 & $\begin{array}{l}390 \\
8 \\
8\end{array}$ & 5 & & 10 he & 10 & 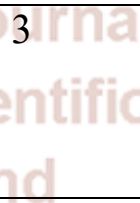 & 3 & $\begin{array}{l}7 \\
3 \\
5 \\
\end{array}$ & 6 & 6 \\
\hline $\begin{array}{l}\text { Tral } \\
\text { Sub-dist. } \\
\text { Hospital }\end{array}$ & 25 & 16 & 9 & $\begin{array}{l}390 \\
6 \quad 0 \\
\end{array}$ & 6 & 8 & 2 & 9 & 4 & 30 & 6 & 6 & 6 \\
\hline $\begin{array}{l}\text { Rajpora } \\
\text { Sub-dist. } \\
\text { Hospital }\end{array}$ & 25 & 12 & 13 & 39 & 7 & & 245 & 10 & 2 & & 7 & 6 & 7 \\
\hline $\begin{array}{l}\text { Vehil } \\
\text { Sub-dist. } \\
\text { Hospital }\end{array}$ & 25 & 9 & 16 & 39 & 4 & & 10 & 12 & 3 & 3 & 6 & 5 & 8 \\
\hline $\begin{array}{l}\text { Zanipora } \\
\text { Sub-dist. } \\
\text { Hospital }\end{array}$ & 25 & 17 & 8 & 39 & 7 & 5 & 2 & 11 & & 4 & 4 & 8 & 6 \\
\hline \multirow{2}{*}{$\begin{array}{l}\text { Keller } \\
\text { Sub-dist. } \\
\text { Hospital }\end{array}$} & 25 & 11 & 14 & 39 & 6 & 6 & 3 & 10 & 2 & 4 & 6 & 6 & 7 \\
\hline & $\begin{array}{l}20 \\
0\end{array}$ & $\begin{array}{l}10 \\
4\end{array}$ & 96 & 39 & 54 & 54 & 18 & 74 & 24 & 28 & 44 & 49 & 55 \\
\hline
\end{tabular}

Source : Field study

Inference :Data analysis was performed to test the level of patient's satisfaction with respect to registration, approach of doctors with patients, free medicines to patients, operation procedure and post operation part towards public hospitals.
The results of the level of patients satisfaction towards registration and approach of doctors with patients in public hospitals is satisfactorily. 
The results of the level of patient's satisfaction towards free medicines, operation procedure and post operative parameters are not satisfactorily. Service quality can provide a value for patients through goods and services. The service is one of the important processes in increasing value for patients. A service from early stages is a service aimed at building relationships with patients. Services provided after the transaction is a service that will always be remembered by the patient. The level of patient satisfaction with good performance services, the level of courtesy and friendliness of nurses and health care facilities. In addition, services such as; the waiting time is too long, especially in the service of the drug; the limited number of officers and registration of drugs; the limited number of cleaning service is not sufficient; service procedure is quite complicated; waiting room air circulation is inadequate; limited room for inpatients; parking space is very limited; hour physician practices must comply with scheduled; patients often have to wait long because the doctor has not come, and the persistence of the practice of brokering the queue number registration section may cause the value to the patient. Major reasons for delivering the poor quality of the services to patients is that majority of the public hospitals are in the main cities of Jammu and Kashmir which are located in big cities like, Jammu, Srinagar, etc. The people living in the rural areas are lacking from the basic health facilities and whenever they have any health problem they have only opportunity to visit these public hospitals located in these big cities. Public hospitals are the only source for the patients, in these two districts for availing from cheap healthcare facilities. This also makes the public hospitals overcrowded and the management is unable to manage the large number of patients. This is the major reason that doctors and staff are unable to provide individual attentions to patients.

\section{Limitations:}

This study has several limitations which do not include control variables such as income level and involve other variables that are considered influential on patient satisfaction, especially government hospitals patients are guaranteed by the universal health coverage. Expected in future studies need to include some factors suspected to affect the patient satisfaction.

\section{Implications:}

Single window mechanism concept need to be developed in Govt. Hospitals Viz Registration, Supply of medicines, ECGs, $\mathrm{X}$ rays etc

For Accident/ Trauma patient separate counters must be there for immediate treatment

$>$ Doctor patient ratio need to be enhanced

$>$ Paramedical staff ratio need to be increased

Hygiene and sanitation especially in wash rooms, bath rooms need to be taken care.

For post operative follow up patients separate OPD room should be put to place

Modern Facilities like C T Scan, MRI be put in place at leastat the district Hospitals and none of the District Hospitals studied have such facilities.

\section{REFERENCES:}

1. Dwarakanath, H. D., \& Raj, P. Y. (2015). National Health Policy - 2015 A Catalyst for Sustainable Development in Primary Health Care. The Monthly Journal Kurukshetra Ministry of Rural Development, Vol. 63, No. 9, Pages 52, Retrieved from http://yojana.gov.in.

2. Freidson, E. (1984). The changing nature of professional control. Annual Review of Sociology, 10, 1-20.

3. Schneider, B., Ashforth, S., Higgs, A.C. and Carr, L. (1996). Design, validity and use of strategically focused employee attitude surveys. Personnel Psychology, Vol. 49, pp. 695-705.

4. Saha, U.R. and Bartlema, J. (1998). User free introduction and quality of care: some empirical indicators from Bangladesh and Comilla. Dhaka: Ministry of Health and Family Welfare; ThanaFunctional Improvement Pilot Project.

5. Braunsberger, K., \& Gates, R. H. (2002). Patient/enrollee satisfaction with healthcare and health plan. Journal of Consumer Marketing, 19(7), 575-590. doi:10.1108/07363760210451401

6. International Finance Corporation (2007) The Business of health in Africa:partnering with the private sector to improve people's lives. Washington (District of Columbia): International Finance Corporation.

7. Weinger S. and Akuri J, (2007). Cameroonian Women's Perceptions of their Health Care Needs. Nordic Journal of African Studies 16(1): 47-63. 